\title{
State-of-the-art Review of Cathodic Protection for Reinforced Concrete Structures
}

\author{
Aimee Byrne \\ Technological University Dublin, aimee.byrne@tudublin.ie \\ Niall Holmes \\ Technological University Dublin, niall.holmes@tudublin.ie \\ Brian Norton \\ Technological University Dublin, brian.norton@tudublin.ie
}

Follow this and additional works at: https://arrow.tudublin.ie/engschcivart

Part of the Catalysis and Reaction Engineering Commons, Construction Engineering and Management Commons, Environmental Engineering Commons, Other Chemical Engineering Commons, Power and Energy Commons, Structural Engineering Commons, Structural Materials Commons, and the Transportation Engineering Commons

\section{Recommended Citation}

Byrne, A., Holmes, N. and Norton, B. (2016) 'State-of-the-art review of cathodic protection for reinforced concrete structures', Magazine of Concrete Research, 68(13), 664-677, 2016. 10.1680/jmacr.15.00083

This Article is brought to you for free and open access by the School of Civil and Structural Engineering at ARROW@TU Dublin. It has been accepted for inclusion in Articles by an authorized administrator of ARROW@TU Dublin. For more information, please contact arrow.admin@tudublin.ie, aisling.coyne@tudublin.ie, gerard.connolly@tudublin.ie.

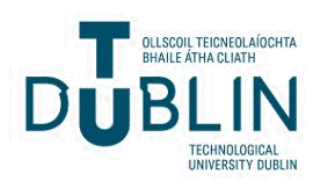




\section{State-of-the-art review of cathodic protection for reinforced concrete structures}

\author{
Aimee Byrne \\ Lecturer, Department of Civil and Structural Engineering, \\ Dublin Institute of Technology, Dublin, Ireland; Dublin Energy Laboratory, \\ Dublin Institute of Technology, Dublin, Ireland \\ (corresponding author: aimee.byrne@dit.ie) \\ Niall Holmes \\ Assistant Head of School, Department of Civil and Structural Engineering, \\ Dublin Institute of Technology, Dublin, Ireland; Dublin Energy Laboratory, \\ Dublin Institute of Technology, Dublin, Ireland
}

\begin{abstract}
Brian Norton
President of DIT, Dublin Energy Laboratory, Dublin Institute of Technology, Dublin, Ireland
\end{abstract}

Cathodic protection (CP) limits the corrosion of a metal surface by making it the cathode of an electrochemical cell. This can be achieved either by using a more active sacrificial anode to create a driving current, or by using inert anodes and impressing a current onto the cathode surface using an external direct current (DC) source. Impressed current cathodic protection (ICCP) is preferred where widespread protection is required, particularly in reinforced concrete structures. ICCP needs a constant DC power supply that is usually provided through a grid connection or independent generators. This paper presents the currently available CP systems for reinforced concrete, particularly ICCP, and the possibility of using self-sufficient and renewable energy systems. The potential for overcoming the mismatch (due to intermittent current) in energy provision from renewable sources with energy needs for CP (constant current) is discussed by exploring methods of storing energy and examining the level of protection provided by intermittent current. Areas that require further research to optimise the design of such systems are highlighted.

\section{Introduction}

Corrosion of reinforcement leads to damage, deterioration and destruction of concrete structures and is therefore a major issue in maintaining infrastructure (Raupach, 2014). Excessive corrosion can be dangerous and costly (Chiu and Lin, 2014; Higuchi and Macke, 2008; Val and Stewart, 2005). The annual cost of corrosion worldwide is estimated to be $3-4 \%$ of the gross domestic product (GDP) of industrialised countries (CIA, 2009; Schmitt, 2009), with US\$17 billion annual maintenance investment reportedly needed to improve bridge conditions in the USA (ASCE, 2009).

There are a number of circumstantial and interconnected influences in designating which repair technique to use, including weight restrictions, budget, the need for a monitoring system, maintenance requirements, traffic management during repairs, the extent and severity of the damage, aesthetics and technical limitations (Pearson and Patel, 2002). Patch repair is the most widely used, but is limited to low-impact localised damage (Qian et al., 2006; Raupach, 2006). The most significant negative impact of this option is the risk of incipient anodes causing corrosion of the surrounding areas of reinforcement (Pearson and Patel, 2002). Coatings and surface treatments are best suited to early chloride or carbon dioxide ingress before the reinforcement is likely to have corroded (Ibrahim et al., 1997; Sivasankar et al., 2013). Surface treatments are usually used as a preventative measure or in combination with other techniques. Coatings are physical barriers to prevent the ingress of chlorides and carbon dioxide. Chemical impregnation with a corrosion inhibitor uses low-viscosity liquids to line the concrete pores (Monticelli et al., 2000; Ngala et al., 2002; Söylev and Richardson, 2008). It has not been established whether inhibitors can readily stop or significantly reduce the rate of corrosion and they may only provide additional protection against initial corrosion; they are therefore only adequate in a small number of circumstances (Pearson and Patel, 2002). Cathodic protection $(\mathrm{CP})$ applies a small current onto the reinforcement, forcing it to act as the cathode as opposed to the dissolving anode in an electrochemical cell. It controls corrosion in the whole area treated, thus reducing the extent of concrete repair (HA, 2002). Chloride extraction is similar to CP but involves a much higher current density and is a one-off application (Miranda et al., 2007; Sánchez and Alonso, 2011). In this technique, chloride ions are drawn out of the concrete towards an anode and are extracted into an electrolyte in the anode. This method is only effective in the cover zone of concrete 
(Pearson and Patel, 2002) and is thought to remove $70 \%$ of chloride ions from this zone. Furthermore, it is not recommended for use with prestressed wires and there is a risk of initiating alkali-aggregate reaction due to the increased $\mathrm{pH}$. Re-alkalisation is an alternative to chloride extraction for carbonated concrete and this is also a one-off treatment (Banfill, 1997; Ribeiro et al., 2013). Carbonation must be quantified and confirmed as the cause of the corrosion before application. There is more leeway with regard to the risk of alkali-aggregate reaction, but this may still occur in areas without carbonation issues. Again, there are limitations to its use with prestressed structures.

As shown in Figure 1, the area of corrosion becomes the anode in an electrochemical cell. A harmless reduction reaction occurs at the non-corroding, cathodic points in the reinforcement. Corrosion can proceed more rapidly in structures exposed to chloride environments such as coastal structures and roads where there is frequent use of de-icing salts. Chloride ions penetrate concrete and destroy the reinforcement's protective passive layer. In the presence of oxygen and water, this causes corrosion. CP is particularly effective where chloride contamination is the cause of corrosion (Polder et al., 2009). As shown in Figure 2, CP involves the introduction of an external anode. The anode is connected to the reinforcement and current flows from the external anode to the reinforcement through the concrete, forcing a beneficial cathodic reaction to occur at the steel surface and creating hydroxyl

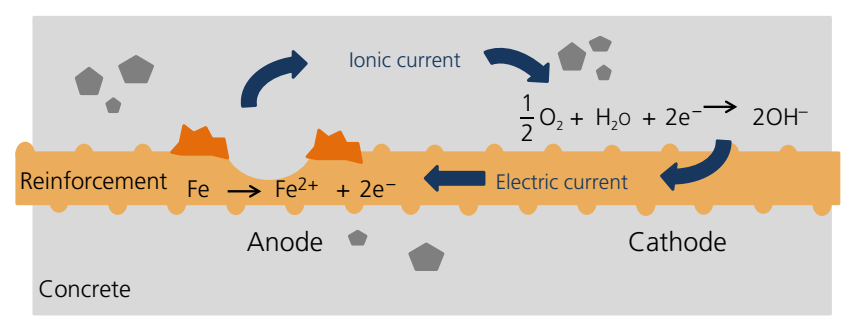

Figure 1. Corrosion of reinforcement in concrete showing oxidation and reduction reactions ions. This increases the $\mathrm{pH}$, and its charge encourages the migration of chloride ions away from the reinforcement (Polder, 1998). As noted earlier, chloride extraction is similar to CP but involves a much higher current density and is a one-off application. For carbonated concrete, re-alkalisation is an alternative to chloride extraction.

The most extensive research on CP has been focused on metal pipelines. Issues examined have included optimising the anode material and position (Abootalebi et al., 2010; Gurrappa, 2005; Konsowa and El-Shazly, 2003; Santana Diaz and Adey, 2005), the degradation of coatings (Chen et al., 2009; Fu and Cheng, 2011) and methods of failure (Liu et al., 2012; Shipilov and Le May, 2006; Xu and Cheng, 2014).

For $\mathrm{CP}$ of reinforced concrete, research has either centred on the anode materials and types used (Bertolini et al., 2004; Jing and $\mathrm{Wu}, 2011$; Parthiban et al., 2008; Wilson et al., 2013; Xu and Yao, 2009), novel monitoring systems (Pruckner et al., 1996; Ward et al., 2014) or examining current distribution within the reinforcement (Hassanein et al., 2002; Xu and Yao, 2009). It has been found that the majority of current is impressed on the reinforcement placed nearest the surface, with little protection afforded to the other layers (BSI, 2012; Hassanein et al., 2002). More severe corrosion rates and higher concrete resistances show less even distribution (Hassanein et al., 2002; Xu and Yao, 2009). However, for a given current distribution, high resistance of the concrete promotes passivation of the steel (Hassanein et al., 2002).

With regard to reinforced concrete, reviews of $\mathrm{CP}$ have been limited to technical reports for industry (Broomfield, 1995; Eltech et al., 1993; Polder et al., 2009; TCS, 2011a) with many of these documents produced in the 1990s when CP was in its infancy. This study is the first to review findings from industry standards and guidelines, corporate experience and academic research on different methods of $\mathrm{CP}$ for reinforced concrete structures. Mindful of the accelerating shift towards renewable energy rooted in European Union and international directives (EC, 2007), alternative energy sources for CP are discussed. The paper identifies research gaps in areas where greater

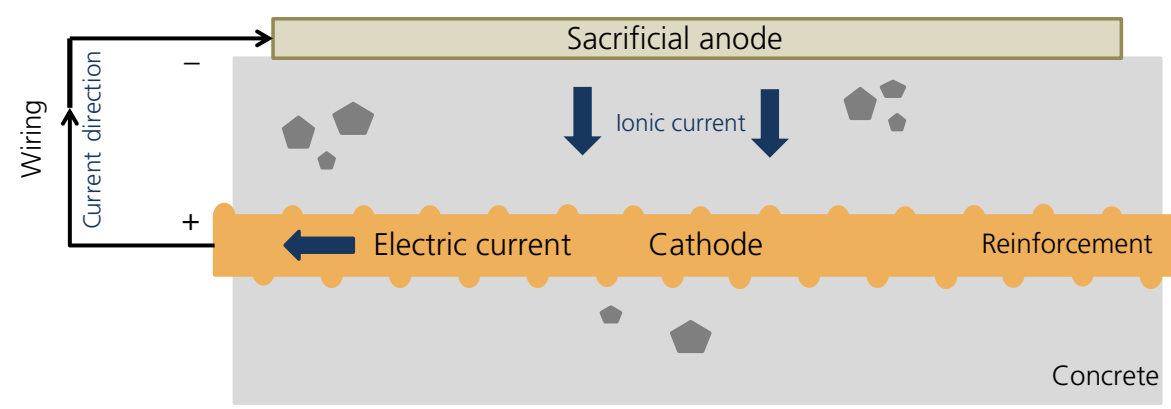

Figure 2. Schematic illustration of SACP for reinforced concrete 
understanding has the potential to create more efficient, sustainable, autarkic systems for the $\mathrm{CP}$ of reinforced concrete structures.

\section{Cathodic protection technologies for reinforced concrete structures}

Preparation for CP firstly involves the removal of cracked or spalled areas of concrete so that the steel can be cleaned superficially before a cementitious mortar is applied. Overlays and mortars should have similar electrical conductivity to the existing structure in order to allow ample current to flow. The continuity of reinforcement is determined using resistance measurements, and any gaps are bridged by welding bars (Polder et al., 2009).

An external anode provides electrons to the reinforcement, making it the cathode and preventing further corrosion (Broomfield, 1995). Due to the high resistivity of concrete, galvanic anodes (as shown in Figure 2) often cannot economically deliver enough current to provide protection. In these cases, the more costly impressed current cathodic protection (ICCP) is used (Wilson et al., 2013), which requires a constant low direct current (DC) power supply. A summary of anode types for sacrificial anode cathodic protection (SACP) and ICCP is given in Table 1.

\section{Sacrificial anode cathodic protection}

Anodes for SACP systems are made from less noble material than the steel being protected (HA, 2002). The difference in electrochemical potentials between the anode and the steel causes a positive current to flow in the electrolyte, from the external anode to the reinforcement, as shown in Figure 2.

The current provided is low, limiting its effectiveness in highresistance environments such as concrete. When this method is used for concrete it is limited to small targeted repairs, where there is limited budget or where the structure has a short life expectancy (Wilson et al., 2013). These systems are often used on oil platforms for both concrete and steel structures below water (Broomfield, 2000). The level of protection and current provided cannot be controlled. Thus, changes in the structure (e.g. the deterioration of a coating) that can cause an increase in protection current demand may necessitate the installation of further anodes.

While a low driving voltage may be undesirable for most reinforced concrete structures, it is a safer option for prestressed structures as there is less risk of hydrogen embrittlement. Furthermore, SACP is less liable to cause interaction on adjacent structures than is ICCP (Kean and Davies, 1981). During such interaction, the flow of current from the $\mathrm{CP}$ anode through the water or soil can go through other nearby structures, causing corrosion at the point where the current leaves the adjacent structure (Chess and Broomfield, 2003).
Interaction can also occur within the same structure if there are metal items not attached to the reinforcement.

SACP systems have a shorter and uncertain lifespan as they are dependent on the average current output and the finite anode material available for sacrifice. New deterioration is the most likely first sign that the anode has been spent. Typical anode materials used are zinc, aluminium and magnesium. These metals are often alloyed to improve the long-term performance and dissolution characteristics. Zinc and its alloys are the most common for concrete structures (Broomfield, 2000); aluminium and magnesium and their alloys are used less regularly (Parthiban et al., 2008) as their oxides and corrosion products can attack the concrete (Broomfield, 2000). The different SACP anodes are described in the following sections.

\section{Metallic coating anodes}

Primary anodes of titanium, stainless steel or brass plates are fixed onto the concrete surface with an insulated epoxy. Then, typically by a high-amperage arc, molten zinc is sprayed onto the concrete with compressed air. This anode type is often used in the splash zone in marine environments (TCS, 2011b). The optimum thickness for metallic zinc is generally between $0.1 \mathrm{~mm}$ and $0.4 \mathrm{~mm}$ (BSI, 2012). Values below this can result in a shorter lifespan of the anode and thicknesses above this range have reduced adhesion to the underlying concrete. This form of anode results in a grey surface finish that can be covered over with a decorative silicon coating.

\section{Anode jackets}

Clamp-on and wrap-around systems are used in splash and higher zones, as well as on concrete piles (TCS, 2011b). A prefabricated fibreglass jacket is supplied with a zinc mesh anode attached to the inside of the jacket using special offsets and the jacket system is mounted onto the pile using compression bands. The void between the jacket and concrete surface is filled with a cementitious grout (Daily, 1999), as shown in Figure 3.

\section{Adhesive zinc sheet anodes}

Rolls of high-purity zinc foil coated on one side with lowresistance ionic conductive hydrogel can be applied directly to a concrete surface (Broomfield, 2000), as shown in Figure 4. Heavy moisture intrusion can degrade the gel, so careful sealing at the edges is important (TCS, 2011b).

\section{Repair/discrete anodes}

Embedded anodes for patch repair are not designed to provide full protection to the steel, but to further the protection provided by patch repair. Normally, at corrosion points in reinforcement, anodic action provides a natural protection to the adjacent steel, making it the cathode. When the damaged area is repaired and patched, the previously protected adjacent 
Atmospherically exposed concrete

Organic coatings (ICCP)

Metallic coatings (ICCP/SACP)

Activated titanium (ICCP)

Conductive cement (ICCP)

Repair/discrete anodes (SACP)

Adhesive zinc sheet (SACP)

Anode jackets (ICCP/SACP)

Immersed concrete

SACP

ICCP

Buried concrete

SACP

ICCP
- Typical current densities 2-20 mA/m², 5-15 year lifespan

- A series of conductors (primary anodes) fixed to the concrete surface or integrated into the coating

- Not suitable for wet structures or wearing surfaces

- Typically 2-20 mA/m², 10-25 year lifespan

- Zinc for SACP and ICCP; aluminium-zinc, aluminium-zinc-indium for SACP; titanium for ICCP

- Primary anodes feed connections of titanium, stainless steel or brass plates fixed to the concrete surface

- One anode per $9 \mathrm{~m}^{2}$ is typical

- Not suitable for wearing surfaces

- Typically limited to long-term maximum of $110 \mathrm{~mA} / \mathrm{m}^{2}, 10-50$ year lifespan (for $200 \mathrm{~mA} / \mathrm{m}^{2}$ )

- Mesh, strip, wire or tube activated titanium anodes, coated with mixed metal oxides with an overlay or cast into slots or drilled holes

- Suitable for wet and wearing surfaces

- Typically 2-20 mA/m², 25+ year lifespan

- Can contain granular carbon or carbon fibres with a metallic coating as the conductive medium

- 25-50 year lifespan

- Prevents the repaired area from causing new anodic corrosion nearby

- Similar discrete anodes can be installed in holes cored or cut into the concrete and wired together

- 25-50 year lifespan

- Rolls of zinc foil are coated on one side with an ionic conductive adhesive gel (hydrogel)

- May be coated

- Expanded anode mesh in permanent glass-reinforced form, grouted to concrete piers, piles or columns

- Titanium mesh used for ICCP; zinc mesh for SACP

- Normally slender stand-off anodes, installed by direct welding to the embedded steel

- For saline waters aluminium-zinc-indium, zinc or magnesium alloys are used (zinc and magnesium can also be used for non-saline waters)

- Can be welded directly to the steel or connected using cabling

- 10-30 A/m length of silicon-iron-chromium (most typical in chloride environments), 200-300 mA/m $\mathrm{m}^{2}$ for lead silver, up to $1000 \mathrm{~mA} / \mathrm{m}^{2}$ for mixed metal oxide coated titanium, up to $3000 \mathrm{~mA} / \mathrm{m}^{2}$ for platinised titanium or niobium

- Rod, tube or strip, mounted directly on the concrete structure or nearby

- Traditional zinc or magnesium alloy anodes may be used

- Can be applied directly or within a chemical backfill (typically gypsum, bentonite and sodium sulfate)

- 1-2 A for a single anode, 5-200 A for clustered ground beds, 10-100 A for deep vertical ground beds

- Embedded in conductive backfill

- Typically high-silicon cast iron (with chromium if in a chloride environment), graphite or mixed metal-oxide-coated titanium

Table 1. Anode types for SACP and ICCP systems (BSI, 2012; HA,

2002; TCS, 2011a, 2011b) 

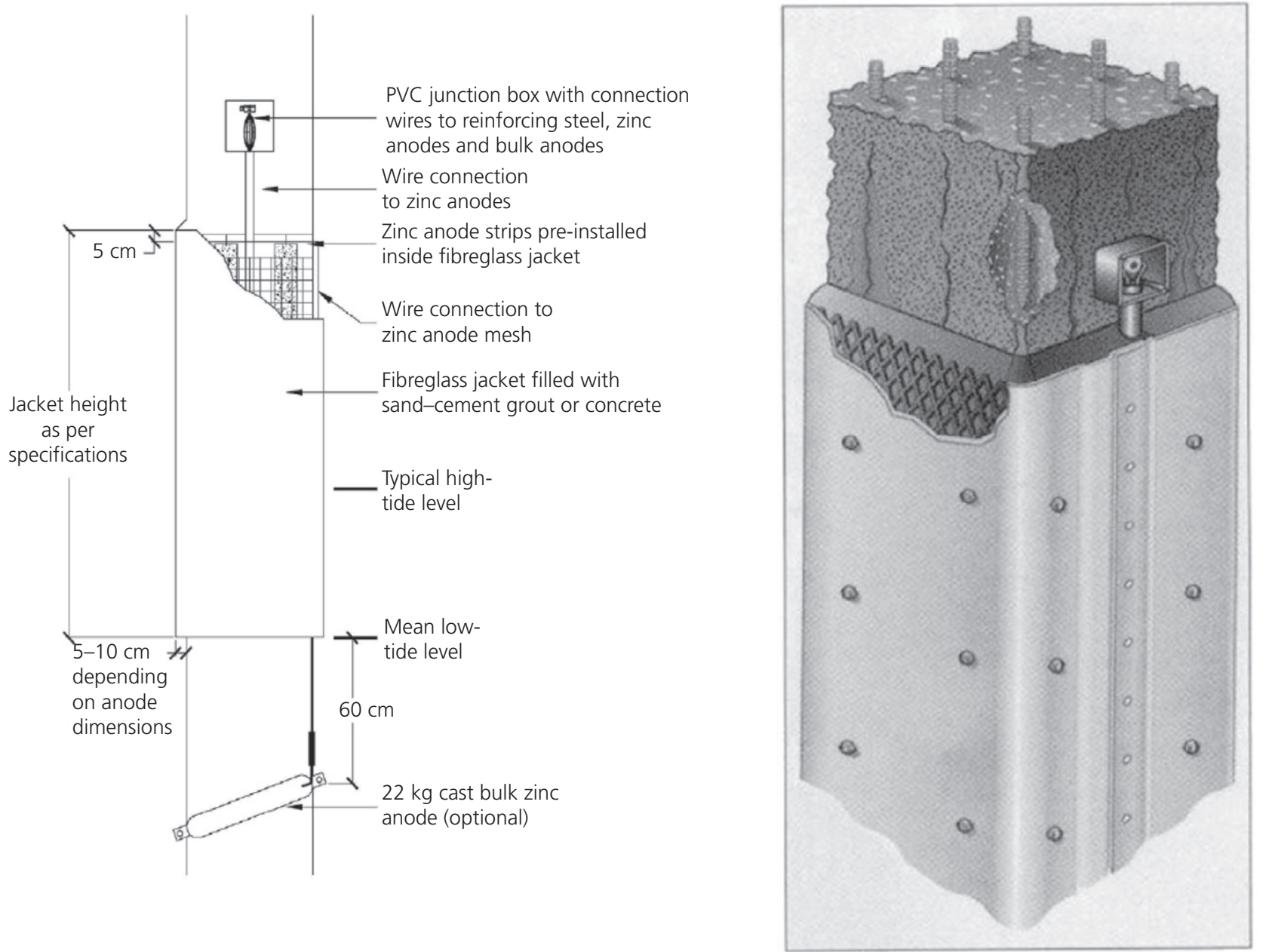

Figure 3. Example of galvanic anode jacket system

(Sohanghpurwala, 2009; VCT, 2012)

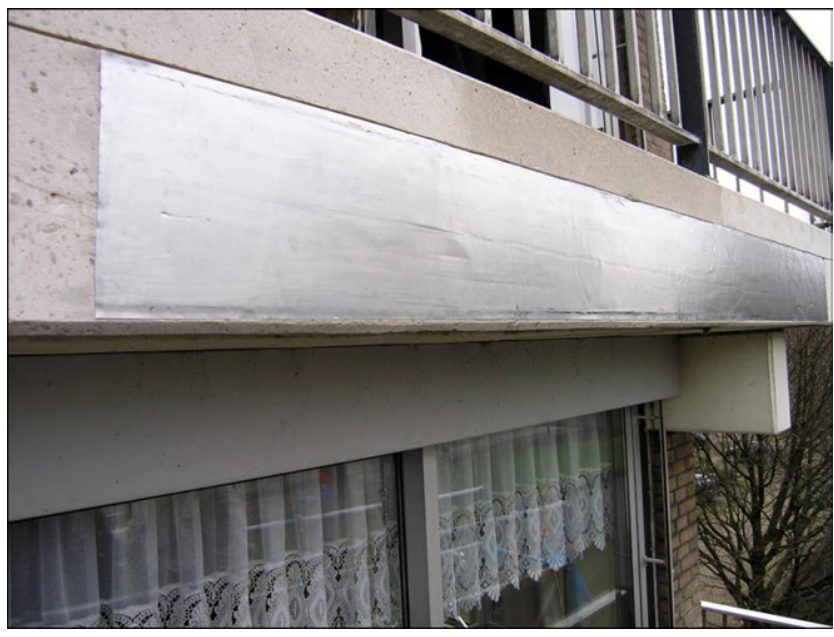

Figure 4. Example of a zinc sheet anode system with gel adhesive (VCT, 2013) lengths of steel can begin to corrode as they are now more active than the repaired portion (Broomfield, 2000). Sacrificial anodes embedded into the patch repair can prevent such an issue (Cheung and Cao, 2013) and further the protection provided by the repair process, as shown in Figure 5. Similar discrete-style anode arrays can also be placed in drilled holes at intervals throughout a concrete structure. These can be designed as stacks of zinc disks on a central zinc core, surrounded by a lithium-based mortar that activates the zinc (TCS, 2011b). Discrete anodes can be connected to the steel directly, either individually or as an array.

\section{Impressed current cathodic protection}

Impressed current cathodic protection is much more commonly used for reinforced concrete than SACP as it can address significant corrosion issues in larger structures with longer life expectancies (Wilson et al., 2013). ICCP systems can control corrosion at any chloride level and, due to their ability to alter 
the current provided, can account for changing protection requirements (Kean and Davies, 1981). The basic elements of an ICCP system are the same as in SACP. However, the external (non-consumable) anode is connected to the positive terminal of a low-voltage DC source (Figure 6). The negative terminal is connected to the reinforcement, through which electrons flow to the steel/concrete interface, thus increasing the cathodic reaction (which produces hydroxide ions from oxygen and water). Hydroxide ions then migrate through the concrete to the anode, oxidising to oxygen and electrons. Electrons then flow to the current source, closing the circuit.

Anodes for ICCP need to be good electrical conductors, have a low rate of corrosion and be able to tolerate high currents without forming resistive oxide layers (Francis, 2014). Examples of anodes for ICCP include magnetite, carbonaceous materials (graphite), high-silicon iron, lead/lead oxide,

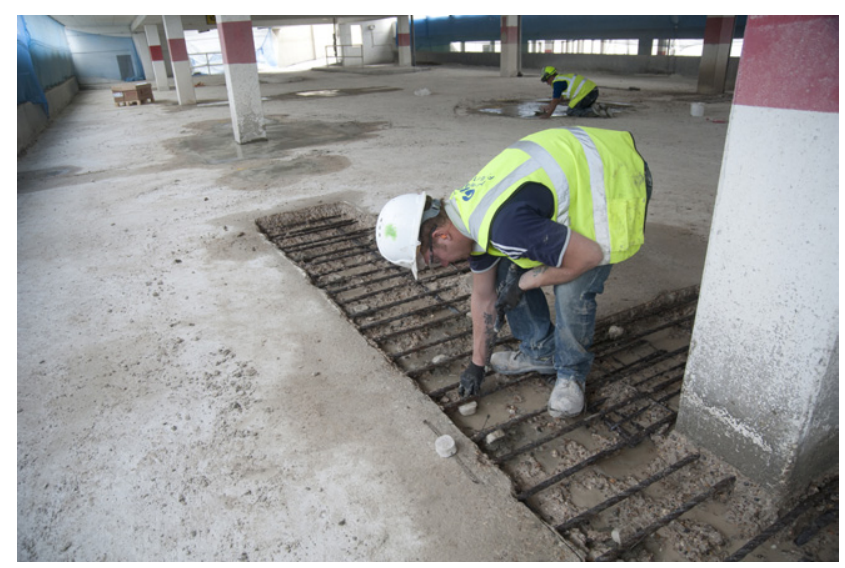

Figure 5. Example of embedded anodes being installed for patch repair before repair mortar is applied (EPMS, 2012) lead alloys and platinised materials such as titanium (Polder et al., 2009). A primary and secondary anode structure is often employed, with the primary anode receiving current and the secondary anode distributing it over the surface of the concrete (Sohanghpurwala, 2009).

In submerged structures the anode may be placed away from the concrete. However, for air-exposed structures the anode must be in direct contact with the concrete due to its high resistance (Broomfield, 1995; Eltech et al., 1993; TCS, 2011a). A distance of $0.2 \mathrm{~m}$ from the anode has been determined to be the maximum effective limit of current spread (Polder et al., 2009). The anodes used for ICCP are described in the following sections.

\section{Activated titanium mesh anodes}

The most common and reliable ICCP anode is an activated titanium expanded mesh coated with mixed metal oxides and covered with a cementitious overlay (Polder et al., 2009). The coating acts as the anode while the titanium provides a stable base (Sohanghpurwala, 2009). Titanium conductors are spot-welded for connection to the current source. Figure 7 shows the fitting of a mesh to a concrete surface using nonmetallic fasteners (a) and being spray-covered with mortar (b). Although titanium mesh/overlay systems are costly and heavy, they are robust, with a high tolerance for external moisture (Polder et al., 2009). Failure of this type of anode system is typically due to disbondment of the overlay, which is attributed to deficiencies in substrate preparation, pre-treatment or application procedures rather than the $\mathrm{CP}$ process (BSI, 2012).

\section{Activated titanium wire/strip/rod anodes}

These smaller anodes are placed in holes or slots and backfilled with a cementitious grout (Polder et al., 2009), and make little difference to the surface appearance of the structure.

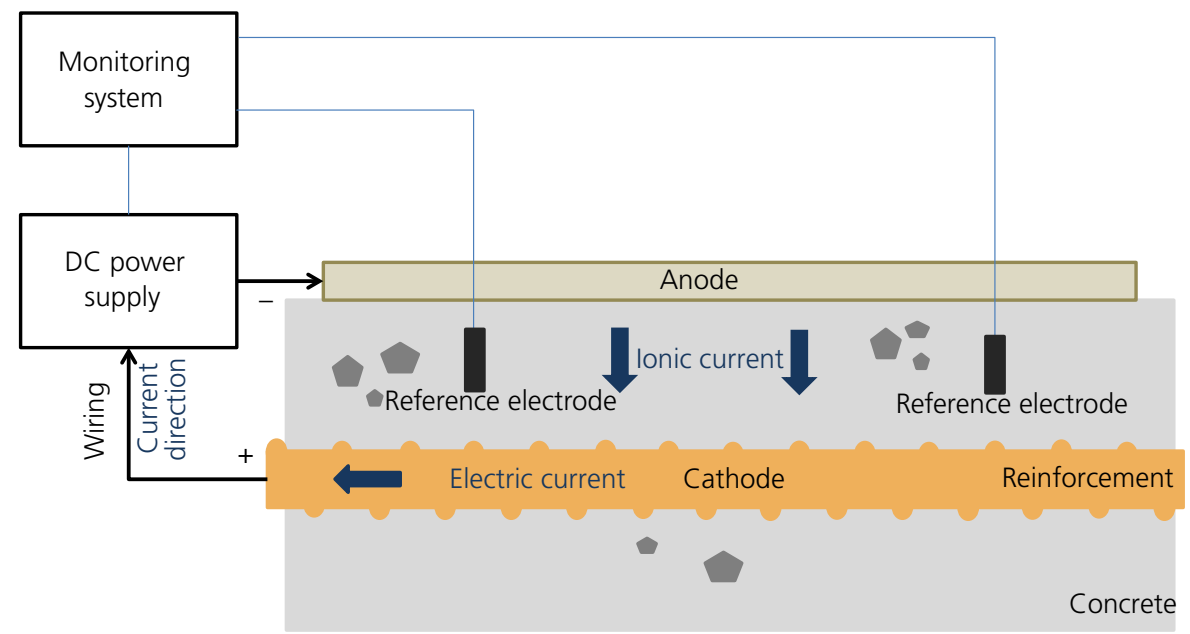

Figure 6. Schematic illustration of ICCP for reinforced concrete 


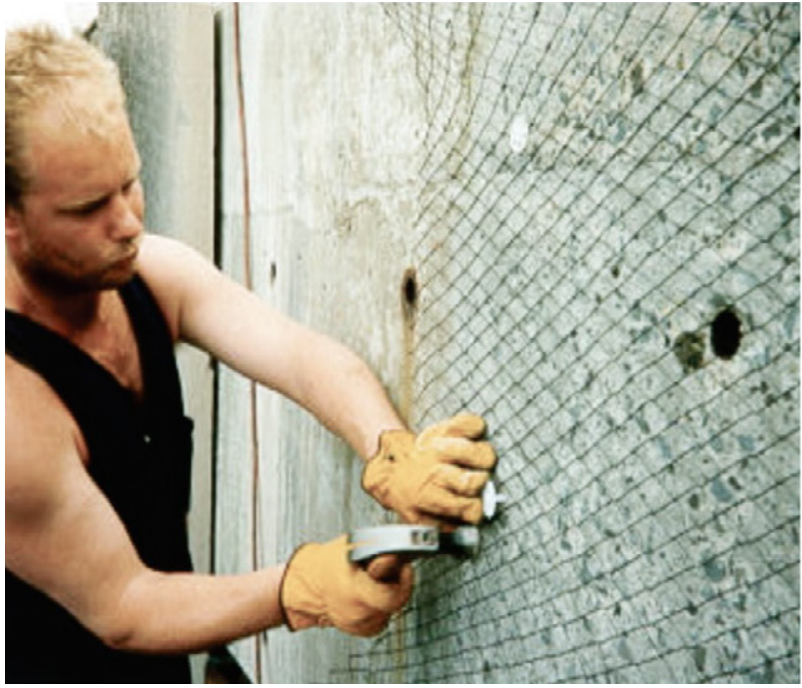

(a)

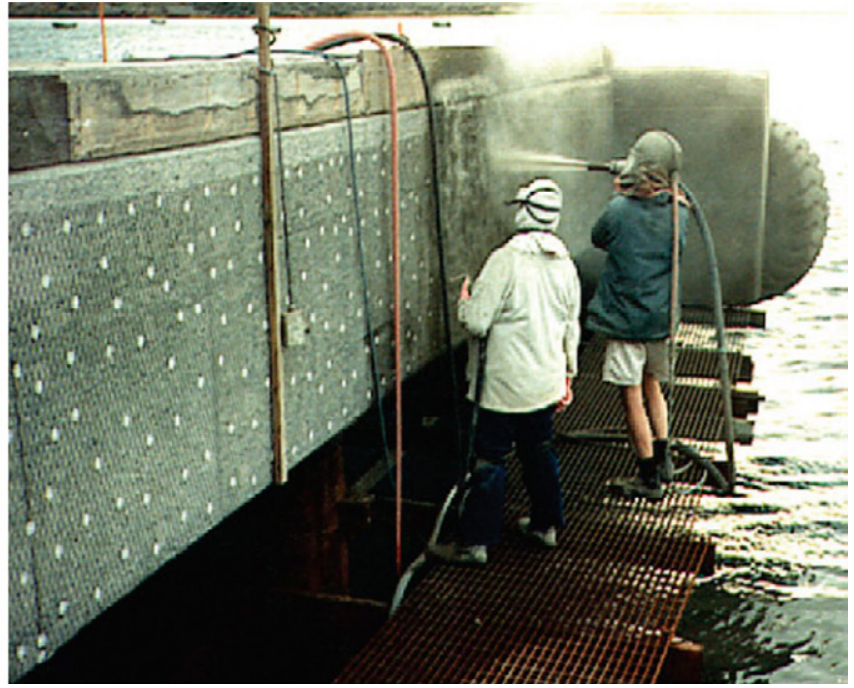

(b)

Figure 7. Example of activated titanium mesh anode application and cover mortar application for ICCP (Araujo et al., 2013)

However, as the anode is inserted into the structure there is a higher risk of short circuits. Schematic illustrations of probe and ribbon anodes are shown in Figure 8.

\section{Organic coating anodes}

Organic anode coatings are applied by brush, roller or air spray to thicknesses of $0 \cdot 25-0 \cdot 50 \mathrm{~mm}$ (BSI, 2012). These coatings are electrically active due to their high proportion of carbon particles (Polder et al., 2009). A series of metallic conductors embedded in the coating act as the primary anode (Figure 9). Coatings containing $45-50 \%$ graphite have been shown to have low resistance and potential stability at high polarisation levels (Orlikowski et al., 2004). However, such levels of graphite increase the porosity of the anode (Darowicki et al., 2003). These systems are light, have a long history of use and are robust with a long life expectancy, but have low tolerance to moisture (Polder et al., 2009). Over time, small defects may appear in the coating but these are not considered to affect performance if less than $100 \mathrm{~mm} \times 100 \mathrm{~mm}$ in size (BSI, 2012). Common failure mechanisms include loss of adhesion or flaking of the coating due to anodic reaction products, which may be acidic (attacking the alkaline concrete) or wetting, which can cause disbondment (BSI, 2012).

\section{Conductive cementitious anodes}

A primary anode such as woven mat is embedded in a polymer-modified cementitious overlay (Polder et al., 2009) and fitted in a similar way to the titanium mesh/overlay system. The anode layer contains either granular carbon or carbon fibres with a metallic coating as the conductive medium. Carbon fibres enhance strength, toughness and electrical performance (Jing and $\mathrm{Wu}, 2011$ ), combining the advantages

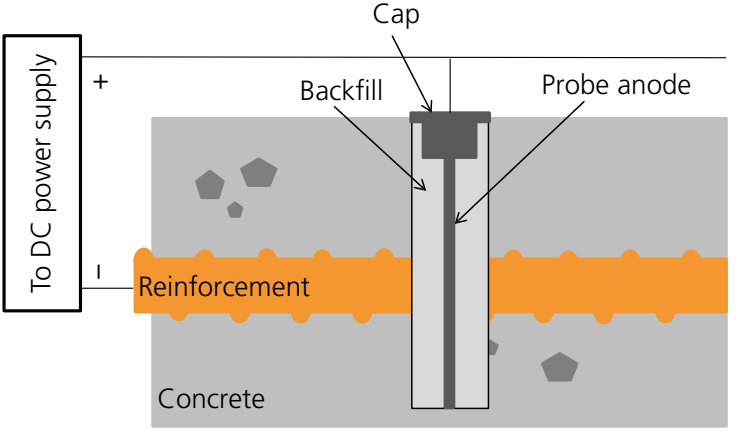

(a)

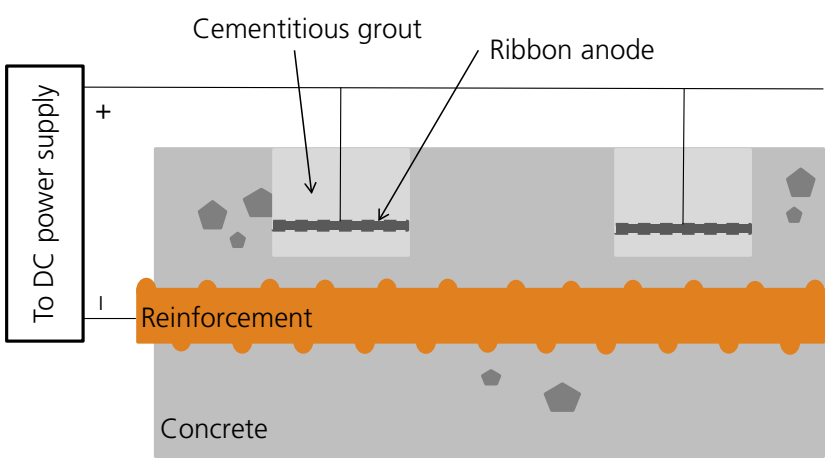

(b)

Figure 8. Probe (a) and ribbon (b) type anodes for ICCP

of titanium mesh and conductive coatings, resulting in a durable system that can still be applied in thin layers and adds little additional weight (Polder et al., 2009). Additives such as pumice aggregate can further reduce the weight 
(Anwar et al., 2014). However, there is little experience with this type of anode, and the higher fibre content means such anodes are more inclined to deteriorate in the presence of chloride ions (Jing and $\mathrm{Wu}, 2011$ ). A protective or cosmetic coating or overlay may also be applied.

\section{Hybrid SACP/ICCP systems}

In hybrid systems, a temporary impressed current is used in conjunction with a low-maintenance galvanic system to restore and maintain alkalinity. This form is used mainly with discrete sacrificial anodes connected to titanium wires for impressing the current (TCS, 2011b).

\section{Comparison of CP methods}

Overall, the benefits of using $\mathrm{CP}$ for reinforced structures compared with other methods include less concrete removal and repair work, a wide variety of choice of anode type, and low monitoring and inspection time and costs (HA, 2002). However, care must be taken to avoid hydrogen embrittlement

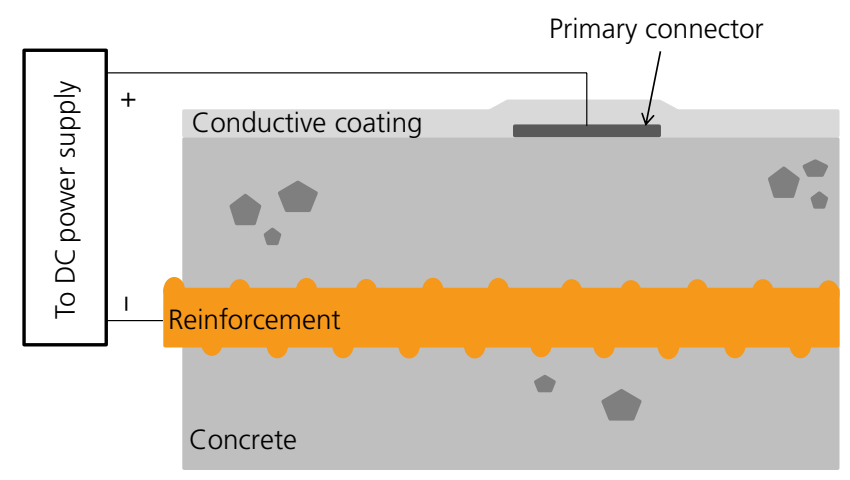

Figure 9. Conductive coating anode for ICCP in the steel, alkali-silica reaction in aggregates and interactions with adjacent structures. Table 2 compares the advantages and disadvantages of SACP and ICCP for reinforced concrete structures.

\section{Power supply and control systems for ICCP}

Normally, for ICCP, the power supply is via a 'transformerrectifier' system (Broomfield, 1995). The transformer reduces the mains voltage and the rectifier converts alternating current (AC) to DC. Due to the complexity of the chloride/moisture/ $\mathrm{pH}$ influence on corrosion, it is not possible to precisely predict the current or potential required. Examples of estimated requirements include $1-5 \mathrm{~A}$ and $2-24 \mathrm{~V}$ to each independently controlled anode zone (Wilson et al., 2013) and $10 \mathrm{~mA}$ and 2-10 V per $\mathrm{m}^{2}$ of surface area of concrete (Broomfield, 1995). The recommended design current density is $20 \mathrm{~mA} / \mathrm{m}^{2}$, referring to the circumferential surface of the bars (Polder et al., 2009). Bridges usually contain over $1 \mathrm{~m}^{2}$ steel surface per $\mathrm{m}^{2}$ of concrete surface. This translates to a typical design current provision of $20 \mathrm{~mA}$ per $\mathrm{m}^{2}$ of surface area of a typical bridge.

ISO 12696:2012 (BSI, 2012) is a performance standard for the design of CP systems for steel in concrete. According to this standard the current supplied to the steel should be held at a constant value. The resistance of mediums can vary with climatic conditions. If the applied DC voltage is held at a constant level, the impressed current on the reinforcement will fluctuate due to the varying resistance of the medium according to Ohm's law (current= voltage/resistance). In these circumstances either over-protection or under-protection can occur. Over-protection can lead to a reduction in the life of the anode and reduced contact between the anode and concrete; this encourages the evolution of hydrogen, which is dangerous in prestressed structures (Polder et al., 2009).

\begin{tabular}{lll}
\hline \multicolumn{1}{l}{ Advantages } & Disadvantages \\
\hline SACP & Simpler to design and install & Less experience in reinforced concrete \\
No external power source & Unable to control current \\
Less liable to cause interaction & Unknown degree of protection \\
No control system & May need to add anodes if current requirements \\
Low risk of hydrogen embrittlement & change \\
& $\begin{array}{l}\text { Shorter lifespan } \\
\text { Commonly used with reinforcement - better understood }\end{array}$ & Not adequate in high-resistance environments \\
ICCP & Need for ongoing DC power supply \\
and greater experience of installers/designers/inspectors & External power and monitoring systems \\
Can use in high-resistance environments & vulnerable to damage and atmospheric corrosion \\
Controllable current & Greater risk of interaction \\
& Greater risk of hydrogen embrittlement
\end{tabular}

Table 2. Advantages and disadvantages of SACP and ICCP

(Broomfield, 2000; HA, 2002; Kean and Davies, 1981) 


\section{Monitoring systems}

Performance monitoring is prescribed at intervals of 3 months for the first year and then every 6 or 12 months thereafter if the performance has been satisfactory (HA, 2002). The shift in potential due to the impressed current indicates the level of protection provided (Nace, 2000). To determine this, a depolarisation test is carried out. The current is switched off and, approximately $1 \mathrm{~s}$ later, the 'instantaneous off' value of polarisation potential is measured. The structure is then allowed to depolarise over the next 4-24 h (Polder et al., 2009). A $100 \mathrm{mV}$ difference is considered sufficient for atmospherically exposed concrete (Nace, 2000; Polder et al., 2009).

Monitoring by depolarisation is based on the use of reference electrodes, usually silver-silver chloride, at representative points in the structure, as shown in Figure 6 (Sohanghpurwala, 2009). The potential of the steel at the concrete interface is measured with respect to these electrodes (TCS, 2011a). Portable reference electrode mechanisms can also be used directly on the concrete surface or in conjunction with Luggin probes (HA, 2002).

Although impressed current systems require regular maintenance and monitoring (BSI, 2012; HA, 2002), one US-based survey found that the majority are not regularly monitored or maintained as the process was considered too burdensome (Sohanghpurwala, 2009). However, Polder et al. (2014) found that major renovation, such as complete replacement of the anode, is rarely required. Most modern systems are now remotely monitored and controlled (Sohanghpurwala, 2009) and automatic depolarisation test setups can be used (V\&C KK, 2014).

\section{Research advances in energy systems for ICCP}

\section{Electrochemical extraction with subsequent CP}

Carefully designed conductive cement pastes allow the same anode to be used for electrochemical chloride extraction (ECE) followed by $\mathrm{CP}$ by changing the current density at the power source. Although anodic overlays can experience some damage during electrochemical treatments due to the acidity produced by the anodic reaction, test results generally show positive findings. A graphite-cement paste anode system was successfully used to provide combined treatment without damaging the anode (Carmona et al., 2015). Similarly, Pérez et al. (2010) showed that there was not sufficient damage to lead to a malfunction of their anodic system when using the combined treatment.

The current density needed for effective $\mathrm{CP}$ may be significantly lowered as a consequence of the reduction of chloride ion content after ECE. However, a disadvantage of using $\mathrm{CP}$ anodes is the impossibility of using the half-cell potential mapping technique for assessing the corrosion state of reinforcement after ECE due to the conductivity of the overlay homogenising the potential values.

\section{Cathodic prevention}

In cathodic prevention the current is applied before corrosion has occurred, usually during construction. Installation costs are lower as the concrete does not need any surface preparation, drilling or finishing (HA, 2002). Cathodic prevention has been used for many years on roads in Italy and concrete structures in aggressive climates in the Middle East (Chess and Broomfield, 2013).

The required current density for cathodic prevention is considerably lower than $\mathrm{CP}$, with examples of $2-5 \mathrm{~mA} / \mathrm{m}^{2}$ (Anis, 1995; Chess and Broomfield, 2003) or $0 \cdot 2-2 \cdot 0 \mathrm{~mA} / \mathrm{m}^{2}$ (BSI, 2012) being estimated. A continuously applied current density of $2 \mathrm{~mA} / \mathrm{m}^{2}$ has been shown to be sufficient even for very severe chloride exposure (Carmona et al., 2015). Even very low current density values $\left(0.4-0.8 \mathrm{~mA} / \mathrm{m}^{2}\right)$ increase the critical chloride threshold for initiating pitting corrosion, but the impact of increasing current closer to the upper limit $\left(1.7 \mathrm{~mA} / \mathrm{m}^{2}\right)$ has been shown to greatly extend protection ability, by a number of years (Bertolini et al., 2009).

\section{Intermittent or low current CP}

If the only impact of $\mathrm{CP}$ is assumed to be the cathodic polarisation of the reinforcement, then - in order to provide adequate protection - the applied current density must be greater than the corrosion rate current (Glass and Buenfeld, 1995). However, Glass et al. (2001) demonstrated that protection may be achieved with a current that is small compared with the corrosion rate (one tenth of the value in their tests). Studies into the effects of $\mathrm{CP}$ on the concrete environment have shown that alkalinity is produced at the cathodically impressed reinforcement as the impressed current uses up the dissolved oxygen, requires hydroxyl ions to carry the ionic current and produces hydrogen (Glass and Chadwick, 1994; McArthur et al., 1993). Where chloride ingress is the cause of corrosion, $\mathrm{CP}$ draws these aggressive ions away from the steel with the flow of negative ionic current (Glass and Chadwick, 1994). Microscopic examinations have revealed that CP can keep chloride ions $100 \mu \mathrm{m}$ away from the steel surface (Koleva et al., 2006).

In research by Glass and co-workers (Glass and Buenfeld, 1995; Glass and Chadwick, 1994; Glass et al., 2001), changes in the environment of the steel (which encourage the creation of the protective passive layer in concrete) continued after current interruption. Intermittent current tests showed results comparable to constant current tests. Similarly, Christodoulou et al. (2010) found that when ICCP was removed after five or more years, the reinforcement remained passive for another year. Kessler et al. (1998) reported that after ICCP is removed from bridge piles, although an amount of depolarisation naturally occurs, the polarisation level can still remain within established CP criteria as long as the initial applied current is sufficiently high. 


\section{Use of renewable energy}

Grid-based and generator power tends to use high fossil fuel consuming sources, with $82 \%$ of global energy demand created by the burning of fossil fuels in 2011 (WEC, 2013). For concrete structures in remote or difficult-to-access locations, power can be supplied by self-sufficient renewable systems such as thermo-electric generators, closed-cycle vapour turbines, wind or solar energy or diesel generators (BSI, 2012; Kean and Davies, 1981; TCS, 2011a).

Originally remote ICCP systems were heavily wind power based (Gipe, 2004). Photovoltaic (PV) modules have since surpassed them in usage, with few examples of other renewable energy sources still present in industry. Both wind and solar systems require batteries or other energy storage mechanisms due to the intermittency of their supply.

Research into renewable energy systems for CP has been predominantly for metallic buried pipelines, occasionally extending to other metallic buried structures such as foundations (Tiba and de Oliveira, 2012). Buried pipelines are the most common application for ICCP, and therefore more research and development has been focused in this area. Furthermore, many buried metal pipelines exist remotely; conversely, most concrete structures requiring protection exist along routeways where there is ready access to grid power. If generators are used, there are easy access routes for maintenance and refuelling.

\section{Photovoltaic systems (for metal pipelines)}

Where examples of renewable energy for ICCP exist in the academic literature, they tend to be for buried metal pipelines rather than reinforced concrete. Solar energy systems are undeniably the most researched (Anis, 1995; El Ghitani and Shousha, 1995; Kharzi et al., 2009; Laoun et al., 2009; Mishra et al., 2000; Mohsen et al., 2013; Tiba and de Oliveira, 2012) and industrially produced renewable energy source used for CP. The basic design of a PV system for attachment to ICCP involves (El Ghitani and Shousha, 1995; Mishra et al., 2000)

- PV modules

a charge controller to prevent batteries overcharging

- batteries to store PV energy; enough to provide the required power for $2 \mathrm{~d}$ is considered adequate ( $\mathrm{El} \mathrm{Ghitani}$ and Shousha, 1995)

- an electronic control unit energised by the storage batteries and acting as a voltage regulator for the load; this part of the system can consist of maximum power point tracking (MPPT)

- auxiliary components of anodes, or reference electrodes, indicating the state of corrosion.

Research within the area of PVs for CP focuses on two separate steps in the system - the management of power going into the batteries (Kharzi et al., 2009; Laoun et al., 2009; Mohsen et al., 2013) and the supply of power from the batteries to the structure being protected (Anis, 1995; El Ghitani and Shousha, 1995; El-Samahy and Anis, 1997; Kharzi et al., 2009; Mishra et al., 2000). Figure 10 shows these separate steps for buried pipelines as derived from different designs (Anis, 1995; Kharzi et al., 2009; Mishra et al., 2000).

\section{Battery-only systems}

Figure 10 highlights the two areas of research in ICCP renewable systems that fit either side of the battery or energy storage

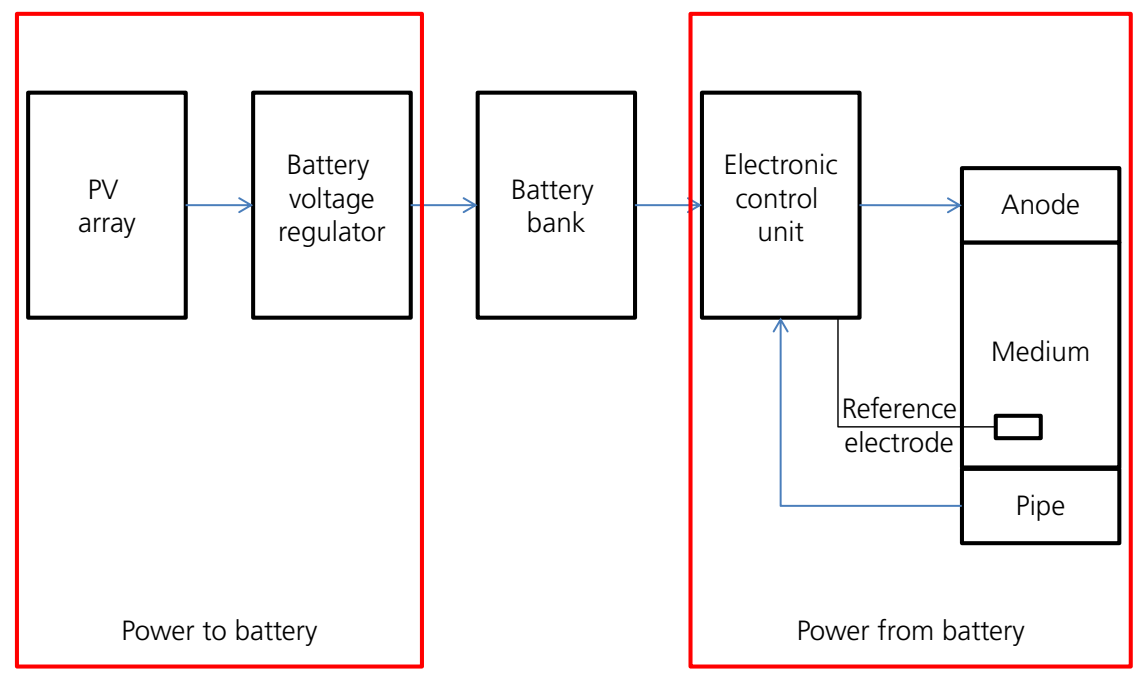

Figure 10. Schematic illustration of the basic elements involved in PV CP systems as based on previous design examples for buried pipelines (Anis, 1995; Kharzi et al., 2009; Mishra et al., 2000) 
system. Batteries have had little focus, even though a batteryonly system may provide adequate protection. Kessler et al. (2000) showed that their purpose-designed batteries provided adequate protection under both laboratory and in situ conditions over 2.5 years. By using battery-only systems, the higher cost of PV-battery systems, which require additional control and wiring mechanisms, is eliminated.

\section{PV-only systems}

As discussed in the section 'Cathodic prevention', the requirement for constant DC supply is questionable. Intermittent energy sources such as PVs may provide adequate protection without the need for energy storage or secondary energy provision.

One piece of research demonstrated that PVs could provide sufficient power for continuous $\mathrm{CP}$ without the need for a storage device. This was achieved by pre-polarising the protected structure to a high negative potential using a temporary DC source before energising for CP (Muehl, 1994). The slow rate of polarisation decay facilitated continuous protection even between supplies of PV current. Another example exists whereby sacrificial anodes were used as the backup energy source for PVs instead of energy storage (Korupp, 1991).

\section{Summary and conclusions}

Corrosion is the major issue in reinforced concrete deterioration, affecting both serviceability and safety. Cathodic protection $(\mathrm{CP})$ has proven to be a reliable long-term solution, particularly in concrete structures exposed to chlorides. This paper presented an overview of the main $\mathrm{CP}$ systems for reinforced concrete structures using up-to-date information from research and industry. The advantages and disadvantages of each form were presented and compared.

Impressed current cathodic protection (ICCP) has been used commonly for reinforced structures as the resistance of concrete requires higher and more controlled protection currents. Activated titanium mesh anode systems are the most regularly used due to their reliability, robustness and even current distribution. However, in structures where weight is an issue, probe, wire or sprayed coating anodes are preferred. ICCP relies on an external DC power source. International targets for 2020 to reduce energy usage by $20 \%$ and increase renewables by $20 \%$ have put pressure to consider alternative and low-energy power sources (EC, 2007). However, specific efforts to make CP more sustainable for reinforced concrete structures have not been observed. There are a number of examples of renewable energy systems for buried metal pipelines in which research tends to focus on either the PV-to-battery step or the battery-to-CP step. It was identified that, within the context of making these systems more efficient, there was a lack of evidence of any such attempts focused on the power storage devices used or novel battery designs that could represent future low-cost solutions.
Standard guidelines suggest a constant DC of $20 \mathrm{~mA} / \mathrm{m}^{2}$ when designing ICCP for concrete. However, much lower values introduced intermittently have proven to be adequate in certain instances. The following two reasons for this have been identified.

- The environment around the steel changes, even at very low current levels, encouraging passivation of the steel and drawing away destructive ions.

- When current is removed, the steel can maintain a slight polarisation that may still be within allowable limits.

Cathodic protection should turn ever more towards renewable sources of energy. A greater understanding of the level and frequency of protection needed could facilitate the design of more efficient systems and advancement in novel and renewable sources of energy. The conclusion of this review is that further research needs to be conducted into the potential for intermittent sources providing adequate protection, renewable energy based $\mathrm{CP}$ and the appropriateness of other novel power sources for ICCP for reinforced concrete structures.

\section{REFERENCES}

Abootalebi O, Kermanpur A, Shishesaz MR and Golozar MA (2010) Optimizing the electrode position in sacrificial anode cathodic protection systems using boundary element method. Corrosion Science 52(3): 678-687.

Anis WR (1995) Design of control circuit of solar photovoltaic powered regulated cathodic protection system. Solar Energy 55(5): 363-366.

Anwar MS, Sujitha B and Vedalakshmi R (2014) Light-weight cementitious conductive anode for impressed current cathodic protection of steel reinforced concrete application. Construction and Building Materials 71: 167-180.

Araujo A, Panossian Z and Lourenco Z (2013) Cathodic Protection for Concrete Structures, vol. 6. Ibracon de Estruturas e Materiais, Sao Paulo, Brazil.

ASCE (American Society of Civil Engineers) (2009) Report Card for America's Infrastructure - Facts about TransportationBridges. American Society of Civil Engineers, Reston, VA, USA.

Banfill PFG (1997) Re-alkalisation of carbonated concrete effect on concrete properties. Construction and Building Materials 11(4): 255-258.

Bertolini L, Bolzoni F, Pastore T and Pedeferri P (2004) Effectiveness of a conductive cementitious mortar anode for cathodic protection of steel in concrete. Cement and Concrete Research 34(4): 681-694.

Bertolini L, Bolzoni F, Gastaldi M et al. (2009) Effects of cathodic prevention on the chloride threshold for steel corrosion in concrete. Electrochimica Acta 54(5): 1452-1463.

Broomfield JP (1995) Cathodic Protection of Reinforced Concrete Status Report. Society for the Cathodic Protection of Reinforced Concrete, Leighton Buzzard, UK. 
Broomfield JP (2000) The Principles and Practice of Galvanic Cathodic Protection for Reinforced Concrete Structures. Technical note 6. Corrosion Prevention Association, Bordon, UK.

BSI (2012) ISO 12696:2012 Cathodic protection of steel in concrete. BSI, London, UK.

Carmona J, Garcés P and Climent MA (2015) Efficiency of a conductive cement-based anodic system for the application of cathodic protection, cathodic prevention and electrochemical chloride extraction to control corrosion in reinforced concrete structures. Corrosion Science 96: $102-111$.

Chen X, Li XG, Du CW and Cheng YF (2009) Effect of cathodic protection on corrosion of pipeline steel under disbonded coating. Corrosion Science 51(9): 2242-2245.

Chess PM and Broomfield JP (2003) Cathodic Protection of Steel in Concrete. Taylor \& Francis, London, UK.

Chess PM and Broomfield JP (2013) Cathodic Prevention Cathodic Protection of Steel in Concrete and Masonry, 2nd edn. CRC Press, Boca Raton, FL, USA.

Cheung MMS and Cao C (2013) Application of cathodic protection for controlling macrocell corrosion in chloride contaminated RC structures. Construction and Building Materials 45: 199-207.

Chiu CK and Lin YF (2014) Multi-objective decision-making supporting system of maintenance strategies for deteriorating reinforced concrete buildings. Automation in Construction 39: 15-31.

Christodoulou C, Glass G, Webb J, Austin S and Goodier C (2010) Assessing the long term benefits of impressed current cathodic protection. Corrosion Science 52(8): 2671-2679.

CIA (Central Intelligence Agency) (2009) The World Fact Book, Country Comparison of GDP. Central Intelligence Agency, Fairfax, VA, USA. See https://www.cia.gov/library/ publications/the worldfactbookrankorder/2004rank.html (accessed 28/11/2014).

Daily S (1999) Using Cathodic Protection to Control Corrosion of Reinforced Concrete Structures in Marine Environments. Corrpro Companies Inc., Corrpro Technical Library, Medina, OH, USA. See http://www.corrpro.co.uk/pdf/ TechnicalPapers/ (accessed 01/12/2014).

Darowicki K, Orlikowski J, Cebulski S and Krakowiak S (2003) Conducting coatings as anodes in cathodic protection. Progress in Organic Coatings 46(3 Spec): 191-196.

EC (European Commission) (2007) Limiting Global Climate Change to 2 Degrees Celsius - The Way Ahead for 2020 and Beyond. Communication from the Commission to the Council, The European Parliament, the European Economic and Social Committee and the Committee of the Regions, Brussels, Belgium.

El Ghitani H and Shousha AH (1995) Microprocessor-based cathodic protection system using photovoltaic energy. Applied Energy 52(2-3): 299-305.
El-Samahy AESM and Anis WR (1997) Microprocessor based control of photovoltaic cathodic protection system. Energy Conversion and Management 38(1): 21-27.

Eltech Research Corporation, Corrpro Companies Inc. and Kenneth C. Clear Inc. (1993) Cathodic Protection of Reinforced Concrete Bridge Elements: A State of the Art Report. Strategic Highway Research Program, National Research Council, Washington, DC, USA. EPMS Supplies (2012). Cathodic Protection. See http://www. epms-supplies.co.uk/c-Cathodic-Protection-(32).aspx (accessed 20/11/2015).

Francis PE (2014) Cathodic Protection. See http://www.npl.co. uk/upload/pdf/cathodic_protection_in_practise.pdf (accessed 02/12/2014).

Fu AQ and Cheng YF (2011) Characterization of the permeability of a high performance composite coating to cathodic protection and its implications on pipeline integrity. Progress in Organic Coatings 72(3): 423-428.

Gipe P (2004) Wind Power: Renewable Energy for Home, Farm, and Business, 2nd edn. Chelsea Green Publishing Company, White River Junction, VT, USA.

Glass GK and Buenfeld NR (1995) On the current density required to protect steel in atmospherically exposed concrete structures. Corrosion Science 37(10): 1643-1646.

Glass GK and Chadwick JR (1994) An investigation into the mechanisms of protection afforded by a cathodic current and the implications for advances in the field of cathodic protection. Corrosion Science 36(12): 2193-2209.

Glass GK, Hassanein AM and Buenfeld NR (2001) Cathodic protection afforded by an intermittent current applied to reinforced concrete. Corrosion Science 43(6): 1111-1131.

Gurrappa I (2005) Cathodic protection of cooling water systems and selection of appropriate materials. Journal of Materials Processing Technology 166(2): 256-267.

HA (Highways Agency) (2002) Design Manual for Roads and Bridges, Cathodic Protection for Use in Reinforced Concrete Highway Structures, vol. 3. Highways Agency, London, UK.

Hassanein AM, Glass GK and Buenfeld NR (2002) Protection current distribution in reinforced concrete cathodic protection systems. Cement and Concrete Composites 24(1): 159-167.

Higuchi S and Macke M (2008) Cost-benefit analysis for the optimal rehabilitation of deteriorating structures. Structural Safety 30(4): 291-306.

Ibrahim M, Al-Gahtani AS, Maslehuddin M and Almusallam AA (1997) Effectiveness of concrete surface treatment materials in reducing chloride-induced reinforcement corrosion. Construction and Building Materials 11(7-8): 443-451.

Jing $X$ and $W u Y(2011)$ Electrochemical studies on the performance of conductive overlay material in cathodic protection of reinforced concrete. Construction and Building Materials 25(5): 2655-2662.

Kean RL and Davies KG (1981) Cathodic Protection, Guide Prepared British Department Trade and Industry, vol. 2-4. National Physical Laboratory, Teddington, UK. 
Kessler RJ, Powers RG and Lasa IR (1998) Intermittent Cathodic Protection Using Solar Power, Corrosion. NACE International, San Diego, CA, USA.

Kessler RJ, Powers RG and Lasa IR (2000) Battery powered impressed current cathodic protection. Proceedings of NACExpo, Orlando, FL, USA, 00815.

Kharzi S, Haddadi M, Malek A, Barazane $L$ and Krishan MM (2009) Optimized design of a photovoltaic cathodic protection. Arabian Journal for Science and Engineering 34(2B): 477-489.

Koleva DA, Hu J, Fraaij ALA et al. (2006) Cathodic protection revisited: impact on structural morphology sheds new light on its efficiency. Cement and Concrete Composites 28(8) 696-706.

Konsowa AH and El-Shazly AH (2003) Rate of zinc consumption during sacrificial cathodic protection of pipelines carrying saline water. Desalination 153(1-3): 223-226.

Korupp KH (1991) Photovoltaic powered cathodic protection systems with advanced system technologies. Proceedings of 10th European Photovoltaic Solar Energy Conference, Lisbon, Portugal, pp. 854-855.

Laoun B, Niboucha K and Serir L (2009) Cathodic protection of a buried pipeline by solar energy. Revenue des Energies Renouvelables 12(1): 99-104.

Liu ZY, Li XG and Cheng YF (2012) Understanding the occurrence of pitting corrosion of pipeline carbon steel under cathodic polarization. Electrochimica Acta 60: 259-263.

McArthur H, D'Arcy S and Barker J (1993) Cathodic protection by impressed DC currents for construction, maintenance and refurbishment in reinforced concrete. Construction and Building Materials 7(2): 85-93.

Miranda JM, Cobo A, Otero E and González JA (2007) Limitations and advantages of electrochemical chloride removal in corroded reinforced concrete structures. Cement and Concrete Research 37(4): 596-603.

Mishra PR, Joshi JC and Roy B (2000) Design of a solar photovoltaic-powered mini cathodic protection system. Solar Energy Materials and Solar Cells 61(4): 383-391.

Mohsen T, Ali A and Iman R (2013) Feasibility of using impressed current cathodic protection systems by solar energy for buried oil and gas pipes. International Journal of Engineering and Advanced Technology 3(2): 222-225.

Monticelli C, Frignani A and Trabanelli G (2000) A study on corrosion inhibitors for concrete application. Cement and Concrete Research 30(4): 635-642.

Muehl WW Sr (1994) Photovoltaic power without batteries for continuous cathodic protection. Proceedings of 4th National Technology Transfer Conference and Exposition. NASA, Washington, DC, USA, pp. 219-222.

Nace (2000) Impressed Current Cathodic Protection of Reinforcing Steel in Atmospherically Exposed Concrete Structures. Nace, Houston, TX, USA.
Ngala VT, Page CL and Page MM (2002) Corrosion inhibitor systems for remedial treatment of reinforced concrete. Part 1: calcium nitrite. Corrosion Science 44(9): 2073-2087.

Orlikowski J, Cebulski S and Darowicki K (2004) Electrochemical investigations of conductive coatings applied as anodes in cathodic protection of reinforced concrete. Cement and Concrete Composites 26(6): 721-728.

Parthiban GT, Parthiban T, Ravi R et al. (2008) Cathodic protection of steel in concrete using magnesium alloy anode. Corrosion Science 50(12): 3329-3335.

Pearson S and Patel RG (2002) Repair of Concrete in Highway Bridges - A Practical Guide. Transport Research Laboratory, Wokingham, UK, AG43.

Pérez A, Climent MA and Garcés P (2010) Electrochemical extraction of chlorides from reinforced concrete using a conductive cement paste as the anode. Corrosion Science 52(5): 1576-1581.

Polder R, Kranje A, Leggedoor J et al. (2009) Guideline for Smart Cathodic Protection of Steel in Concrete. Assessment and Rehabilitation of Central European Highway Structures, FEHRL, Brussels, Belgium.

Polder RB (1998) Cathodic protection of reinforced concrete structures in the Netherlands - experience and developments: cathodic protection of concrete -10 years experience. Heron 43(1): 3-14.

Polder RB, Leegwater G, Worm D and Courage W (2014) Service life and life cycle cost modelling of cathodic protection systems for concrete structures. Cement and Concrete Composites 47: 69-74.

Pruckner F, Theiner J, Eri J and Nauer GE (1996) In-situ monitoring of the efficiency of the cathodic protection of reinforced concrete by electrochemical impedance spectroscopy. Electrochimica Acta 41(7-8): 1233-1238.

Qian S, Zhang J and Qu D (2006) Theoretical and experimental study of microcell and macrocell corrosion in patch repairs of concrete structures. Cement and Concrete Composites 28(8): 685-695.

Raupach M (2006) Patch repairs on reinforced concrete structures - model investigations on the required size and practical consequences. Cement and Concrete Composites 28(8): 679-684.

Raupach M (2014) History of Efc-Wp11 'Corrosion in Concrete'. Institute for Building Materials Research of Aachen University, Aachen, Germany.

Ribeiro PHLC, Meira GR, Ferreira PRR and Perazzo N (2013) Electrochemical realkalisation of carbonated concretes influence of material characteristics and thickness of concrete reinforcement cover. Construction and Building Materials 40: 280-290.

Sánchez M and Alonso MC (2011) Electrochemical chloride removal in reinforced concrete structures: improvement of effectiveness by simultaneous migration of calcium nitrite. Construction and Building Materials 25(2): 873-878. 
Santana Diaz E and Adey R (2005) Optimising the location of anodes in cathodic protection systems to smooth potential distribution. Advances in Engineering Software 36(9): 591-598.

Schmitt G (2009) Global Needs for Knowledge Dissemination, Research, and Development in Materials Deterioration and Corrosion Control. World Corrosion Organisation, New York, NY, USA.

Shipilov SA and Le May I (2006) Structural integrity of aging buried pipelines having cathodic protection. Engineering Failure Analysis 13(7): 1159-1176.

Sivasankar A, Arul Xavier Stango S and Vedalakshmi R (2013) Quantitative estimation on delaying of onset of corrosion of rebar in surface treated concrete using sealers. Ain Shams Engineering Journal 4(4): 615-623.

Sohanghpurwala AA (2009) Cathodic Protection for Life Extension of Existing Reinforced Concrete Bridge Elements. Transportation Research Board,Washington, DC, USA.

Söylev TA and Richardson MG (2008) Corrosion inhibitors for steel in concrete: state-of-the-art report. Construction and Building Materials 22(4): 609-622.

TCS (The Concrete Society) (2011a) Cathodic Protection of Steel in Concrete. The Concrete Society, Camberley, UK.

TCS (2011b) Cathodic Protection of Steel in Concrete Appendices. The Concrete Society, Camberley, UK.

Tiba C and de Oliveira EM (2012) Utilization of cathodic protection for transmission towers through photovoltaic generation. Renewable Energy 40(1): 150-156.

Val DV and Stewart MG (2005) Decision analysis for deteriorating structures. Reliability Engineering \& System Safety 87(3): 377-385.
V\&C KK (V\&C Kathodischer Korrosionsschutz Ges.m.b.H) (2014) Cathodic Protection of Reinforced Structures. See http://www.vc-austria.com/fileadmin/media/downloads/ broschueren/englisch/vc_reinforced_concrete_protection.pdf (accessed 10/11/2014).

VCT (Vector Corrosion Technologies) (2012) Galvanode Jacket Data Sheet. Vector Corrosion Technologies, Winnipeg, MB, Canada.

VCT (2013) Galvanode Zincsheet Data Sheet. Vector Corrosion Technologies, Winnipeg, MB, Canada.

Ward C, Nanukuttan S and McRobert J (2014) The performance of a cathodic protection system in reinforced concrete structure: monitoring and service life modelling. Proceedings of Civil Engineering Research in Ireland (CERI), Belfast, Northern Ireland, http://dx.doi.org/10. 13140/2.1.4462.4962.

WEC (World Energy Council) (2013), World Energy Resources 2013, Survey Summary. 23rd edition. World Energy Council, London, UK.

Wilson K, Jawed M and Ngala V (2013) The selection and use of cathodic protection systems for the repair of reinforced concrete structures. Construction and Building Materials 39: $19-25$.

Xu J and Yao W (2009) Current distribution in reinforced concrete cathodic protection system with conductive mortar overlay anode. Construction and Building Materials 23(6): 2220-2226.

Xu LY and Cheng YF (2014) Experimental and numerical studies of effectiveness of cathodic protection at corrosion defects on pipelines. Corrosion Science $\mathbf{7 8}$ $162-171$. 